\title{
Tax Minimization Pemoderisasi Tunnelling Incentive, Mechanism Bonus dan Debt Covenant dalam Pengambilan Keputusan Transfer Pricing
}

Priscillia Aulia Rahma ${ }^{1}$, Djoko Wahjudi ${ }^{2}$

DOI: https://doi.org/10.35838/jrap.2021.008.02.13

1 Universitas Stikubank Semarang, Jawa Tengah, Semarang

¿Universitas Stikubank Semarang, Jawa Tengah, Semarang

\section{ARTICLE INFO \\ JEL Classification: \\ $\mathrm{H} 21 ; \mathrm{H} 32$}

Key words: tunnelling incetive, mechanism bonus, debt covenant, tax minimization, transfer pricing.

\begin{abstract}
This study aims to determine the effect of income tunneling incentive, mechanism bonus and debt covenant on transfer pricing indications with tax minimization moderitation variables. This study is conducted using a case study with a qualitative research method. The data used is secondary data in form of evidence, historical records or reports that have been compiled in published and unpublished archives (documentary data). The research population uses manufacturing companies listed on the Indonesia Stock Exchange (IDX) in 2018-2020. The sampling technique was carried out by purposive sampling method. The study uses 505 observational data. Logistic regression is a data analysis technique used in this study. The result of the research that tunnelling incentives, mechanism bonus and debt covenant with tax minimization variable moderating have an effect on transfer pricing indications.
\end{abstract}

\begin{abstract}
ABSTRAK
Penelitian ini bertujuan untuk mengetahui pengaruh tunneling incentive, mekanisme bonus dan debt covenant terhadap indikasi transfer pricing dengan tax minimization sebagai variabel moderisasi. Strategi penelitian yang digunakan adalah studi kasus dengan metode penelitian kualitatif. Data yang digunakan adalah data sekunder berupa bukti, catatan atau laporan historis yang telah tersusun dalam arsip (data dokumenter) yang dipublikasikan dan yang tidak dipublikasikan. Populasi penelitian menggunakan perusahaan manufaktur yang terdaftar di Bursa Efek Indonesia (BEI) tahun 2018-2020. Teknik pengambilan sampel dilakukan dengan metode purposive sampling. Penelitian menggunakan 505 data observasi. Regresi logistik merupakan teknik analisis data yang digunakan dalam penelitian ini. Hasil penelitian menunjukkan bahwa tunnelling incentive, mechanism bonus dan debt covenant dengan tax minimization sebagai variabel pemoderisasi berpengaruh terhadap keputusan melakukan transfer pricing.
\end{abstract}

\section{PENDAHULUAN}

Sejak Perjanjian Umum tentang Tarif dan Perdagangan (GATT) masuk ke Organisasi Perdagangan Dunia, kesehatan (globalisasi) untuk mendongkrak perusahaan multinasional. Karena itu, transaksi antar negara juga mengalami peningkatan, sehingga batas antar negara tetap konsisten hampir tidak ada di bagian lain negara itu. Hal yang sama berlaku untuk modal investasi mengalir dari satu negara ke negara lain untuk meningkatkan lalu lintas perdagangan internasional atau transnasional / kegiatan komersial. Keadaan tersebut membutuhkan keterampilan untuk mengeksplorasi potensi penerimaan fenomena aktivitas ini. Sebagian besar transaksi perdagangan internasional menjalin penggabungan perusahaan multinasional ke 
dalam grup (transaksi intra-grup) dan menjadi semakin kompleks karena tidak hanya berarti barang modal, jasa, dan real estate (kekayaan intelektual). Jadi, tunduk pada kompleksitas analisis untuk tujuan perpajakan. Di banyak negara, perpajakan merupakan pendapatan yang cukup besar. Perpajakan merupakan salah satu elemen terbesar dalam pendapatan pemerintah Indonesia. Oleh karena itu, pemerintah Indonesia melakukan pengawasan ketat terhadap pelaksanaan perpajakan dalam rangka menjaga perpajakan nasional. Pajak adalah pajak yang dikenakan kepada individu atau badan. Pajak adalah pajak yang dikenakan pada negara. Orang atau badan ini wajib berdasarkan hukum dan digunakan untuk kemakmuran sebesar-besarnya negara. Perusahaan berusaha membayar pajak sesedikit mungkin tagihan pajaknya karena pajak akan mengurangi pendapatan bersih, dan bagi pemerintah pajak setinggi mungkin akan berguna bagi manajemen pemerintah untuk mengumpulkan dana.

Penghindaran pajak (tax avoidance) adalah upaya penghindaran pajak legal karena tidak ada pelanggaran peraturan perpajakan karena metode dan teknik yang digunakan dengannya memanfaatkan kelemahan yang ada dalam hukum dan peraturan perpajakan dapat mengurangi jumlah pajak yang terutang (Pohan, 2016). Tindakan ini menjadi pembangunan pemerintah, karena nilai pajak anggaran tahunan tidak sesuai dengan implementasinya. Pemerintah berharap semua wajib pajak membayar pajak dan membayar uang pajak ke perbendaharaan dengan benar dan jujur. Dalam konteks pemerintahan Indonesia, Berbagai regulasi untuk mencegah penggelapan pajak. Salah satu aturannya Misalnya terkait transfer pricing, yakni terkait penerapan prinsip kewajaran dan normalitas bisnis transaksi antara wajib pajak dan para pihak orang dengan hubungan khusus (Perdirjen No. PER-43 / PJ / 2010, 2010).

Dapat dikatakan bahwa banyak wajib pajak di Indonesia yang sengaja melakukan tindakan penghindaran pajak sehingga mengakibatkan penurunan pendapatan nasional. Menurut laporan tahunan Badan
Pajak Umum, sesuai Keputusan Presiden Nomor 72 Tahun 2020, penerimaan pajak negara dari tahun 2020 hingga Agustus 2020 adalah 676,9 triliun atau menyumbang $56,5 \%$ dari target penerimaan pajak tahun ini. Pada akhir Agustus turun 15,6\% (www.kemenkeu.go.id).

Faktor lain yang memungkinkan perusahaan mengambil keputusan transfer pricing adalah tunnelling incentive. Tunneling adalah transfer sumber daya pemegang saham pengendali dalam perusahaan. Pemindahan sumber daya dapat dilakukan dengan berbagai cara, salah satunya melalui harga transfer. (Sarawasti dan Sujana, 2017) menemukan bahwa tunneling incentives berdampak positif bagi perusahaan dalam pengambilan keputusan transfer pricing.

Debt covenant merupakan faktor lain yang mendorong perusahaan untuk mengambil tindakan menerapkan transfer pricing. Debt covenant adalah kontrak yang ditujukan pada peminjam oleh kreditur untuk membatasi aktivitas yang mungkin merusak nilai pinjaman dan recovery pinjaman, Cochran, (2001) dalam (Pambudi, 2017). Debt covenant adalah perjanjian yang dirancang untuk melindungi pemberi pinjaman dari pelanggaran manajer, agar tidak merugikan kepentingan kreditur, seperti dividen yang berlebihan, atau membiarkan aset jatuh di bawah level yang telah ditentukan. Menurut (Watts, 1986) motif pemilihan suatu metode akuntansi tidak terlepas dari teori akuntansi positif, salah satunya adalah debt covenant hypothesis.

Keputusan untuk melakukan transfer pricing juga dipengaruhi oleh mekanisme bonus (mevhanism bonus). Jika rencana kinerja adalah target laba jangka panjang (tiga atau lima tahun), maka bentuk kompensasi yang paling populer adalah penggajian, paket asuransi, opsi saham yang tidak memenuhi syarat, hak penghargaan saham dan rencana bonus. Mengingat mekanisme bonus bisa dari indeks trend laba bersih yang akan mempengaruhi transfer pricing, dan kemudian direktur dan manajer akan mengambil tindakan untuk menyesuaikan laba bersih, 
memaksimalkan bonus yang akan mereka terima.

Variabel tax minimization dalam penelitian Mispiyanti (2015) menunjukkan bahwa tax minimization tidak berpengaruh signifikan terhadap transfer pricing sedangkan dalam penelitian Refgia (2017), F, Mayowan, \& Karjo (2016), Hartati et al. (2015), Nurjanah et al. (2015) menunjukkan bahwa tax minimization berpengaruh signifikan terhadap transfer pricing.

Motivasi dari penelitian ini adalah banyaknya perusahaan yang bergerak di bidang penghindaran pajak. Misalnya, perusahaan yang melakukan ini di Indonesia adalah Bank BCA, dan perusahaan terkenal lainnya di luar negeri, seperti Apple Inc, Starbucks, dan Facebook. Oleh karena itu, peneliti berharap dapat mempelajari lebih lanjut dampak ukuran perusahaan, return on asset, leverage, intensitas modal, pertumbuhan penjualan, dan komposisi spesialis independen. Kemudian, hasil kajian tersebut sebenarnya dapat dijadikan acuan untuk pengelolaan perusahaan dan pihak terkait transaksi, serta bantuan bahan pertimbangan kebijakan pemerintah tentang masalah transfer pricing multinasional.

Berdasarkan latar belakang tersebut, maka rumusan masalah dalam penelitian ini yaitu: (1) Apakah transfer pricing berpengaruh terhadap penghindaran pajak perusahaan? (2) Apakah tunnelling incentive berpengaruh terhadap keputusan perusahaan melakukan penghindaran pajak? (3) Apakah debt covenant menggunakan proksi dari tingkat leverage terhadap indikasi penghindaran pajak? (4) Apakah secara signifikan peran tax minimization mempengaruhi tunnelling incentive, mechanism bonus dan debt covenant terhadap transfer pricing.

\section{TELAAH TEORI PENGEMBANGAN HIPOTESIS}

DAN

\subsection{Telaaah Teori}

\subsubsection{Teori Keagenan (Agency Theory)}

Teori keagenan adalah teori yang muncul antara dua pihak terlibat kedua belah pihak setuju dengan negara tempat layanan akan digunakan. Hubungan keagenan adalah kontrak di mana satu atau beberapa orang (principal) mempekerjakan orang lain atau satu pihak (agen) untuk melakukannya berbagai layanan dan memberdayakan pembuat keputusan. Ini menunjukkan bahwa manajemen memiliki tanggung jawab untuk bertanggung jawab atas semua keputusan tentang pengguna laporan keuangan, termasuk investor, pemangku kepentingan, pemegang saham dan kreditor. Misalnya, dalam kontrak karyawan, pemilik perusahaan adalah pihak principal dan manajemen puncak adalah agen, yang dipekerjakan untuk menjalankan perusahaan atas nama pemilik (untuk pemilik).

Teori keagenan menurut Jensen dan Meckling (1976) adalah "suatu kontrak di bawah satu atau lebih yang melibatkan agen untuk melaksanakan beberapa layanan bagi mereka dengan melakukan pendelegasian wewenang pengambilan keputusan kepada agen". Diasumsikan bahwa baik pelaku maupun pelaku ekonomi adalah rasional dan hanya dimotivasi oleh kepentingan mereka sendiri. Jika kedua belah pihak memiliki tujuan yang sama untuk memaksimalkan nilai perusahaan, maka dapat diasumsikan bahwa agen akan bertindak untuk kepentingan independen. Sebagai pihak yang berwenang, agen akan mencoba memaksimalkan imbalan (reward) yang diterimanya, yang bergantung pada tingkat upaya yang telah dilakukan. Di sisi yang lain para manajer berusaha memaksimalkan return yang berasal dari pengelolaan sumber daya yang telah diserahkan kepada agen dan upaya ini bergantung pada imbalan jasa yang dibayarkan kepada agen (Herawaty \& Anne, 2019).

Pada kasus transfer pricing dapat terjadi jika terdapat transaksi antar entitas bisnis yang memiliki hubungan istimewa. Hal ini menjadi peluang transaksi dengan entitas terkait yang menyebabkan terjadinya benturan kepentingan, hal ini sesuai dengan teori agensi. Pada perusahaan tertentu yang memiliki banyak divisi dalam satu grup tentu akan memiliki berbagai kepentingan yang bertentangan dengan berbagai tugas yang berbeda. Hal ini dapat membuat pemegang 
saham menjadi rugi, hal ini dikarenakan pemegang saham tidak terlibat langsung dalam pengelolaan perusahaan sehingga berkaitan dengan praktek transfer pricing yang dilakukan perusahaan (Marfuah dan Noor Azizah, 2014).

\subsubsection{Transfer Pricing}

Definisi dari transfer pricing dapat dibagi menjadi dua, yaitu arti dari transfer pricing yang netral dan bermakna pejorative. Pengertian netral penetapan transfer pricing adalah sebuah strategi yang tidak ada bisnis dengan insentif untuk mengurangi beban pajak. Pada saat yang sama, makna pejorative dengan asumsi transfer pricing adalah upaya menyimpan beban pajak dengan cara tertentu dengan menggeser keuntungan ke tarif pajak rendah (Suandy, 2011).

Dalam studi Yuniasih et al. (2013) transfer pricing dihitung menggunakan dikotomi, yaitu adanya penjualan kepada pihak terkait (hubungan istimewa. Transfer pricing diproksikan dengan nilai Related Party Transaction (RPT) dalam (Nuradila \& Wibowo, 2018).

$$
\text { RPT }=\frac{\text { Piutang RPT }}{\text { Total piutang }} \times 100 \%
$$

\subsubsection{Tunnelling incentive}

Variabel tunnelling incentive dalam penelitian ini diukur dengan persentase rasio kepemilikan saham asing melebihi 20\%. Berdasarkan Pernyataan Standar Akuntansi Keuangan (PSAK) No. 15 (Pernyataan Standar) Akuntansi Keuangan (PSAK), 2019) bahwa entitas mempunyai pengaruh signifikan baik secara langsung atau tidak langsung (melalui anak perusahaan) termasuk menyertakan modal 20\% atau lebih. (Noviastika F et al., 2016) Pemegang saham Pengendali dapat mentransfer sumber daya dari perusahaan ke dirinya sendiri dengan cara berikut yaitu transaksi antara perusahaan dan pemilik, seperti penjualan aset, kontrak transfer pricing.

\subsubsection{Mechanism bonus}

Mekanisme bonus merupakan salah satu strategi dalam akuntansi, dirancang untuk memberi penghargaan kepada dewan direksi atau manajemen perusahaan sehingga dewan atau manajemen akan berusaha bekerja keras, termasuk melakukan aktivitas transfer pricing untuk mendapatkan bonus berikutnya.

Mekanisme bonus adalah imbalan yang dilakukan pemilik perusahaan kepada manajer karena memenuhi sasaran kinerja perusahaan, manajer bisa mendapatkan bonus sesuai laba bersih atau sesuai target pertumbuhan laba bersih (Hansen dan Mowen, 2005). Lo et al (2010) mengatakan manajer lebih memilih meningkatkan laporan laba dengan meningkatkan laba penjualan dari pihak terkait (jika ada bonus) dengan menggunakan indeks laba bersih (ITRENDLB).

$$
\text { ITRENDLB }=\frac{\text { Laba bersih tahun } \mathrm{t}}{\text { Laba bersih tahun } \mathrm{t}-1} \times 100 \%
$$

\subsubsection{Debt Covenant}

Perjanjian hutang (debt covenant) adalah perjanjian yang dapat dilindungi oleh pemberi pinjaman dari administrator yang merugikan kepentingan kreditor. Debt covenant hypothesis memprediksi bahwa manajer ingin meningkatkan pendapatan, dan Aset yang mengurangi biaya kontrak hutang saat perusahaan memutuskan perjanjian hutang (Nuradila \& Wibowo, 2018).

Identifikasi kontrak hutang, yaitu dengan menggunakan DER (Debt to Equity Ratio). Debt covenant diproksikan dengan rasio hutang atau rasio leverage. DER adalah rasio antara total hutang dengan ekuitas, jadi anda bisa melihat besarnya hutang perusahaan jika dibandingkan dengan jumlah saham yang dimiliki perseroan atau pemegang saham. Semakin besar nilai DER, semakin besar nilainya sehingga hutang yang dimiliki perusahaan sangat memungkinkan perusahaan mengandalkan hutang untuk mendanai operasi dibandingkan dengan dana perusahaan sendiri. 


$$
\text { DER }=\frac{\text { Total liablitas }}{\text { Total ekuitas }} \times 100 \%
$$

\subsubsection{Tax Minimization}

Tax minimization adalah strategi yang dilakukan oleh perusahaan untuk meminimalkan beban pajak perusahaan. Penelitian Rahayu (2010) mengemukakan bahwa modus transfer pricing dilakukan dengan cara merekayasa pembebanan harga transaksi antar perusahaan yang memiliki hubungan istimewa, dengan tujuan untuk meminimalkan beban pajak terutang secara keseluruhan. Selanjutnya, Mangoting (2000) mengungkapkan bahwa praktik transfer pricing sering digunakan oleh banyak perusahaan sebagai alat untuk meminimalkan taksiran pajak yang harus dibayar. Penelitian serupa mengemukakan bahwa beban pajak yang semakin besar memicu perusahaan untuk melakukan transfer pricing dengan harapan dapat menekan beban tersebut (Yuniasih, 2012).

Meminimalkan pajak juga bisa diukur menggunakan proksi ETR saat ini dengan membandingkan antara beban pajak kini dan laba sebelum pajak (Cahyadi \& Noviari, 2018). Tapi ketika dalam penelitian ini proksi yang digunakan adalah cash ETR. Riset dengan cash ETR dibawakan oleh Hartina (2018) dan Kiswanto \& Purwaningsih (2014). Cash ETR adalah rasio pajak tunai yang dibayarkan atas laba pajak penghasilan perusahaan untuk tahun tersebut.

$$
\text { ETR }=\frac{\text { Tax expense }}{\text { Laba kena pajak }} \times 100 \%
$$

\subsection{Pengembangan Hipotesis}

\subsubsection{Pengaruh tunnelling incentive terhadap keputusan transfer pricing}

Dalam agency theory sudah dijelaskan bahwa pemegang saham pengendali atau mayoritas dapat memindahkan seluruh sumber daya perusahaan pada dirinya sendiri melalui transaksi antara perusahaan dengan pemilik. Hal tersebut dapat dilakukan dengan menjual aset, pemberian pinjaman, dan lain-lain Serta, pemegang saham pengendali atau mayoritas dapat meningkatkan porsi atas perusahaan tanpa harus memindahkan aset melalui penerbitan saham dilutif maupun transaksi keuangan lainnya yang mengakibatkan kerugian bagi pemegang saham non pengendali atau minoritas

Yuniasih et al., (2012) menemukan bahwa tindakan tunnelling incentive berpengaruh positif pada ketentuan transfer pricing ", kondisi untuk konsentrasi ekuitas perusahaan terdaftar di Indonesia untuk tunnelling incentive oleh pemegang saham utama.

Maka dari uraian di atas dapat dikembangkan hipotesis sebagai berikut :

\section{H1 : Tunnelling incentive berdampak positif pada pengambilan keputusan transfer pricing.}

\subsubsection{Pengaruh mechanism bonus terhadap keputusan transfer pricing}

Dalam agency theory sudah dijelaskan bahwa pemberian rencana bonus dimana batas atas bonus sebagian bergantung pada rasio pembayaran dividen perusahaan (untuk mengurangi masalah retensi dividen), membayar manajer lebih berdasarkan pergerakan harga saham ketika manajer mendekati masa pensiun (untuk mengurangi masalah horizon), membayar bonus pada tingkat progresif ketika keuntungan yang dilaporkan meningkat (untuk meminimalkan masalah penghindaran risiko) dan remunerasi manajer dikurangi dengan kompensasi berbasis saham ketika kepemilikan manajer di perusahaan meningkat (untuk mengurangi masalah penghindaran risiko).

Mengacu pada studi Lo et al. (2010) di Amerika Serikat, mereka menemukan manajemen cenderung menggunakan transaksi transfer pricing untuk memaksimalkan bonus yang mereka terima, jika bonusnya berdasarkan keuntungan. Sehingga dapat disimpulkan, bahwa manajer akan cenderung menerapkan tindakan untuk menyesuaikan 
pendapatan bersih melalui praktik transfer pricing untuk memaksimalkan bonus mereka.

Maka dari uraian di atas dapat dikembangkan hipotesis sebagai berikut :

H2 : Mechanism bonus berdampak positif pada pengambilan keputusan transfer pricing.

\subsubsection{Pengaruh debt covenant terhadap keputusan transfer pricing}

Dalam agency theory sudah dijelaskan bahwa pengontrakan utang (debt covenant) sangat erta kaitannya dengan teori keagenan, dimana dalam prakteknya para investor selaku pemilik perusahaan mewakilkan pengelolaan sumber daya dalam perusahaan kepadapihak yang dikontrakyaitu manajeruntuk dapat menghasilkan return yang menguntungkan bagi pihak perusahaan. Perantara yang digunakan untuk mengukur debt convenant adalah rasio leverage. Rasio ini berguna untuk memberikan gambaran mengenai struktur modal milik perusahaan, sehingga dapat terprediksi risiko tak tertagihnya utang dalam perusahaan.

Penelitian yang dilakukan oleh Susanti (2015) menunjukkan bahwa analisis faktorfaktor yang mempengaruhi keputusan perusahaan melakukan transfer pricing variabel debt covenant tidak berpengaruh signifikan terhadap keputusan melakukan transfer pricing. Hasil sebaliknya terpadat pada penelitian Sundari dan Yugi (2016) menemukan bahwa debt covenant tidak memiliki pengaruh yang signifikan terhadap keputusan perusahaan dalam melakukan transfer pricing. Namun hasil penelitian yang dilakukan oleh Ria et al. (2017) menunjukkan bahwa debt covenant berdampak transfer pricing.

Maka dari uraian di atas dapat dikembangkan hipotesis sebagai berikut :

H3 : Debt covenant berdampak positif pada pengambilan keputusan transfer pricing.

\subsubsection{Pengaruh tax minimization dalam memoderasi tunnelling incentive terhadap keputusan transfer pricing}

Dalam agency theory, transfer pricing sendiri merupakan salah satu bentuk dari penghindaran pajak. Jika tunneling terjadi di perusahaan, maka mereka akan mengorbankan shareholders minoritas dengan menerapkan transfer pricing yang diperkuat dengan insentif untuk meminimalisir pajak dengan adanya motivasi tax minimization.

Dengan stimulus dapat mengurangi beban pajak akan memperkuat hubungan tunneling incentives dengan transfer pricing (Nuradila \& Wibowo, 2018). Penelitian yang sama menemukan bahwa beban pajak yang semakin besar memicu perusahaan untuk melakukan transfer pricing dengan harapan dapat menekan beban tersebut (Yuniasih, 2012).

Maka dari uraian di atas dapat dikembangkan hipotesis sebagai berikut:

H4 : Tax minimization dapat memoderasi dampak positif dalam hubungan tunnelling incentive terhadap keputusan transfer pricing.

\subsubsection{Pengaruh tax minimization dalam memoderasi mechanism bonus terhadap keputusan transfer pricing}

Dalam agency theory, hipotesis rencana bonus menjelaskan bahwa manajer akan cenderung memilih kebijakan akuntansi yang dapat mentransfer pendapatan masa depan ke periode berjalan untuk menerima bonus. Jika bonus mereka bergantung pada jumlah pendapatan bersih, maka mereka dapat meningkatkan bonus selama periode tersebut dengan melaporkan pendapatan bersih setinggi mungkin, karena mereka juga menginginkan bonus yang tinggi.

(Nuradila \& Wibowo, 2018), (Amanah \& Suyono, 2020), (Rahmawati Nila \& Mulyani Susi Dwi, 2020) mengemukakan bahwa penghindaran pajak tidak dapat memitigasi dampak mekanisme bonus terhadap keputusan transfer pricing perusahaan multinasional. (Nazihah et al., 2019), pajak perusahaan berdampak positif pada transfer pricing.

Maka dari uraian di atas dapat dikembangkan hipotesis sebagai berikut :

H5 : Tax minimization memperkuat dampak positif dalam hubungan mechanism bonus terhadap keputusan transfer pricing. 


\subsubsection{Pengaruh tax minimization dalam modernisasi debt covenant terhadap keputusan transfer pricing}

Dalam agency theory, semakin cenderung suatu perusahaan melanggar perjanjian hutang maka manajer akan cenderung memilih prosedur akuntansi yang dapat mentransfer laba periode mendatang ke periode masa kini, karena hal tersebut dapat mengurangi risiko "default". Debt covenant menjelaskan bagaimana manajer menyikapi perjanjian hutang. Manajer dalam menyikapi adanya pelanggaran atas perjanjian hutang yang jatuh tempo, akan berupaya menghindarinya dengan memilih kebijakan akuntansi yang menguntungkan.

(Nuradila \& Wibowo, 2018), (Amanah \& Suyono, 2020), (Yulianti \& Rachmawati, 2019) menyatakan bahwa tax minimization tidak memoderasi pengaruh debt covenant terhadap ketetapan transfer pricing. Sebaliknya, makin tinggi rasio hutang atau ekuitas makin dekat perusahaan dengan batas perjanjian atau peraturan kredit (Kalay, 1982).

Maka dari uraian di atas dapat dikembangkan hipotesis sebagai berikut :

H6 : Tax minimization memperkuat dampak positif dalam hubungan debt covenant terhadap keputusan transfer pricing.

\section{METODE PENELITIAN}

\subsection{Populasi dan Sampel}

Populasi (population) adalah sekelompok orang, kejadian atau segala sesuatu yang mempunyai karakteristik tertentu. Populasi dalam penelitian ini adalah seluruh perusahaan manufaktur terdaftar di Bursa Efek Indonesia (BEI) dari 2018 hingga 2020. Populasi pada penelitian ini diperoleh 584 data laporan keuangan. Dalam penelitian kuantitatif, sampel adalah bagian dari jumlah dan karakteristik yang dimiliki oleh populasi tersebut. Bila populasi besar, dan peneliti tidak mungkin mempelajari semua yang ada pada populasi, misalnya karena keterbatasan dana, tenaga dan waktu, maka peneliti dapat menggunakan sampel yang diambil dari populasi itu. Serta yang dijadikan sampel dalam penelitian ini hanya dikhususkan pada perusahaan yang bergerak di bidang manufaktur dengan kriteria tertentu.

\subsection{Metode Pengambilan Sampel}

Sampel digunakan dalam penelitian ini digunakan metode non profitability sampling yaitu purposive sampling. Metode purposive sampling ini adalah metode yang menentukan kriteria khusus untuk tujuan tertentu guna mendapatkan sampel yang cukup representative (mewakili populasi). Standar sampel untuk penelitian ini adalah sebagai berikut :

1. Untuk perusahaan yang dikendalikan perusahaan asing, rasio kepemilikan 20\% atau lebih. Menurut PSAK 15, yang mengatur tentang pemegang saham bahwa pengendali (shareholders) adalah objek yang memiliki saham atau surat berharga $20 \%$ atau lebih dari aset bersih. Ketika entitas memiliki pengaruh langsung atau secara tidak langsung, seperti anak perusahaan yang memiliki $20 \%$ atau lebih hak suara investee, entitas tersebut dianggap memiliki pengaruh signifikan.

2. Perusahaan manufaktur yang terdaftar di Bursa Efek Indonesia (BEI) tahun 2018-2020.

3. Perusahaan yang tidak melaporkan kerugian selama periode 2018-2020. Jika perusahaan mengalami kerugian, maka perusahaan tidak akan dikenakan biaya yang memungkinkan wajib pajak membayar pajak sehingga untuk mencapai relevansi penelitian ini, kerugian akan dihapus dari sampel.

\subsection{Skala Pengukuran Variabel}

Uma Sekaran (2000:187) mendefinisikan skala : A scale a tool mechanism by which individuals are distinguished on the variables of interest to our study. The scale or tool could be a grossone in the sense that it would only broadly categorize individuals on certain variables; or it could be a fine-tuned increases progressively as we move from the nominal to the ratio scale. Jadi skala yaitu kategori respon ataupun item yang menunjukkan ukuran dari suatu variabel, baik kualitatif maupun kuantitatif. Skala pengukuran variabel adalah seperangkat 
aturan yang digunakan untuk mengkuantitatifkan data dari pengukuran suatu variabel.

Definisi operasional dalam melakukan penelitian transnasional, penting untuk diingat bahwa beberapa variabel memiliki arti berbeda dan signifikan dalam kebudayaan yang

berbeda. Penyusunan skala sebagai bagian dari kepekaan terhadap definisi operasional dalam kajian budaya. Budaya yang berbeda bereaksi terhadap persoalan penyusunan skala.

Identifikasi variabel dan definisi operasional secara terperinci dapat dinyatakan sebagai berikut :

Tabel 1

Pengukuran Variabel

\begin{tabular}{lll}
\hline \multicolumn{1}{c}{ Variabel } & \multicolumn{1}{c}{ Pengukuran } & Skala \\
\hline Variabel Dependen : & RPT & Rasio \\
Transfer Pricing & & \\
Variabel Independen: & & \\
Tunnelling incentive & Kepemilikan saham asing & Rasio \\
Mechanism Bonus & ITRENDLB & Rasio \\
Debt Covenant & DER & Rasio \\
Variabel Moderating: & ETR & Rasio \\
Tax minimization & & \\
\hline
\end{tabular}

Sumber : Data diolah tahun 2021

\subsection{Teknik Analisis Statistik Deskriptif}

Teknik analisis data yang digunakan dalam penelitian ini adalah metode analisis data kuantitatif dengan menggunakan program Statistical Package for Social Science (SPSS). Analisis data dilakukan dengan menggunakan teknik analisis regresi logistik. Teknik ini digunakan karena variabel dependen dalam penelitian ini bersifat dikotomi atau merupakan variabel dummy. Teknik analisis yang digunakan dalam penelitian ini adalah statistik deskriptif. Variabel bebas dalam model regresi linear ini adalah berganda (lebih dari satu) adalah berganda, dan untuk data yang memenuhi asumsi standar dan asumsi lebih lanjut, model regresi linier berganda adalah model regresi yang tepat untuk digunakan (Refgia, 2017). Untuk membuktikan hipotesis dalam penelitian ini, maka data yang diperoleh analisis dengan model regresi linier berganda. Uji linier berganda ini dapat dilakukan dengan 2 (dua) model, antara lain :

\section{Model 1}

Uji regresi linier berganda variabel independen terhadap keputusan transfer pricing tanpa variabel moderating.

$$
\begin{array}{ll}
\mathrm{Y} & =\mathrm{a}+\beta 1(\mathrm{TI})+\beta 2(\mathrm{ITRENDLB})+\beta 3(\mathrm{DER}) \\
& +\mathrm{e}
\end{array}
$$

Keterangan :

Y

a

$$
\text { } \beta 1 \ldots \beta 6 \quad \text { = Koefisien Regresi }
$$

TI =Tunnelling Incentive $(X 1)$

ITRENDLB = Mechanism Bonus (X2)

DER $\quad=$ Debt Covenant $(\mathrm{X} 3)$

e $\quad=$ Residual Error

\section{Model 2}

Uji regresi linier berganda variabel independen dengan variabel moderating tax minimization terhadap transfer pricing.

Sebelum pengujian hipotesis, uji hipotesis klasik juga akan dilakukan berupa uji normalitas, uji multikolinearitas, uji autokorelasi dan uji heteroskedastisitas. 
Hipotesis ini akan diuji dengan menggunakan analisis regresi berganda, yaitu menggunakan rumus matematika berikut :

$$
\begin{aligned}
\mathrm{Y} & =\mathrm{a}+\beta 1(\mathrm{TI})+\beta 2(\text { ITRENDLB })+\beta 3(\mathrm{DER}) \\
& +\beta 4(\mathrm{TI} * \mathrm{TM})+\beta 5(\text { ITRENDLB*TM })+\beta 6 \\
& \left(\mathrm{TI}{ }^{*} \mathrm{DER}\right)+\mathrm{e}
\end{aligned}
$$

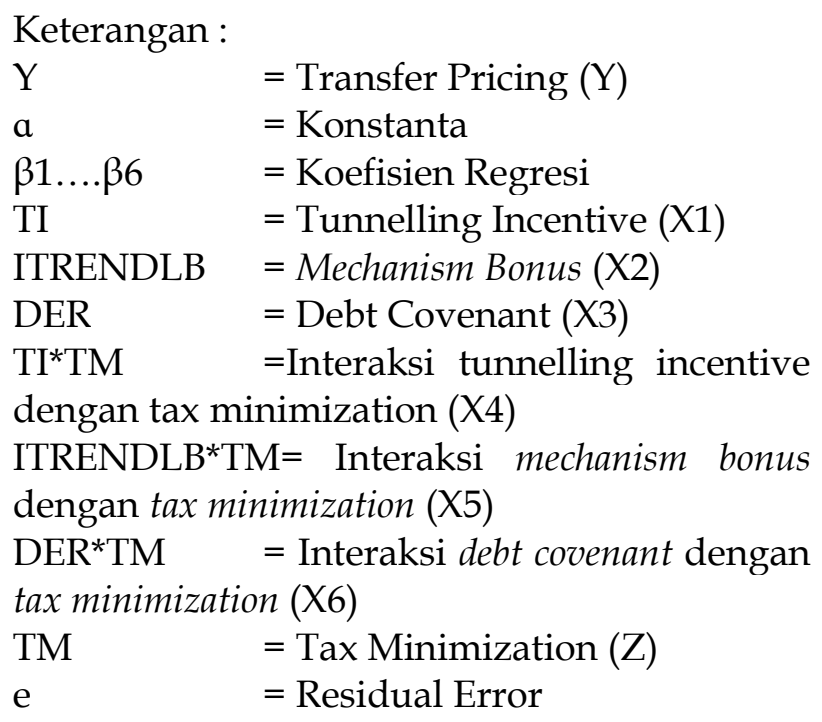

\subsection{Analisa Regresi}

\subsubsection{Uji Normalitas}

Uji normalitas bertujuan untuk menguji apakah dalam model regresi, variabel pengganggu atau residual memiliki distribusi normal. Ada 2 cara mendeteksi apakah residual berdistribusi normal atau tidak, yaitu dengan analisis grafik dan uji statistik (melihat nilai kurtosis dan skewness dari residual dan uji statistik non-parametrik Kolmogorov-Smirnov (K-S)).

\subsubsection{Uji Asumsi Klasik}

\subsubsection{Uji Multikolinearitas}

Multikolinearitas adalah hubungan yang linear atau hubungan antara satu variabel bebas (independen variabel) atau variabel prediktor dengan variabel prediktor lainnya di dalam sebuah model regresi. Uji multikolinearitas adalah uji yang dilakukan untuk memastikan apakah di dalam sebuah model regresi ada interkorelasi atau kolinearitas antar variabel bebas.

\subsubsection{Uji Autokorelasi}

Autokorelasi muncul karena observasi yang berurutan sepanjang waktu berkaitan satu sama lainnya. Masalah ini timbul karena residual tidak bebas dari satu pengamatan ke pengamatan lainnya. Hal ini sering ditemukan pada data time series karena residual pada seseorang individu atau kelompok cenderung mempengaruhi residual pada individu atau kelompok yang sama atau pada periode berikutnya. Uji autokorelasi hanya digunakan untuk data time series seperti laporan keuangan dan lain-lain. Sedangkan untuk data cross section (seperti penyebaran kuesioner) maka data tersebut tidak membutuhkan dilakukan uji autokorelasi.

\subsubsection{Uji Heteroskedastisitas}

Uji heteroskedastisitas bertujuan untuk menguji apakah dalam model regresi linear terjadi ketidaksamaan variance dari residual satu pengamatan ke pengamatan yang lain (Ghozali, 2018:137). Model regresi yang baik adalah yang homoskedastisitas atau tidak terjadi heteroskedastisitas. Adapun cara mendeteksi ada atau tidaknya heteroskedastisitas, yaitu Spearman' rho, Uji Glejser, Uji Park, dan Melihat Pola Grafik. Pengujian ini dilakukan dengan uji Glejser yaitu meregresi masing-masing variabel independen dengan absolute residual sebagai variabel dependen.

\subsubsection{Uji Kelayakan Model}

\subsubsection{Analisis Koefisien Determinasi $\left(\mathbf{R}^{2}\right)$}

Koefisien Determinasi menunjukkan suatu proporsi dari varian yang dapat diterangkan oleh persamaan regresi (regression of sum squares, RSS) $(\hat{Y}-\mathrm{Y}) 2$ terhadap varian total (total sum of squares, TSS)(Y - Y)2.

Koefisien Determinasi $\left(\mathrm{R}^{2}\right)$ mengukur seberapa jauh kemampuan model dalam menerangkan variasi variabel terikat (dependen) . Nilai koefisien determinasi dilihat dari nilai Adjusted $\mathrm{R}^{2}$ yaitu antara nol dan satu. 


\subsubsection{Uji Signifikansi Simultan (Uji Statistik F)}

Uji $\mathrm{F}$ digunakan untuk mempengaruhi variabel secara bersama-sama (simultan) terhadap variabel dependen / terikat (Ghozali, 2016). Jika nilai $F$ lebih besar dari pada nilai 4 maka Ho ditolak pada derajat kepercayaan 5\% atau 0,05 dengan kata lain menerima hipotesis alternatif, yang menyatakan secara serentak dan signifikan mempengaruhi variabel dependen.

\subsubsection{Pengujian Hipotesis (Uji Statistik t)}

Hipotesis adalah suatu pernyataan mengenai nilai suatu parameter populasi yang dimaksudkan untuk pengujian dan berguna untuk pengambilan keputusan. Pengujian hipotesis adalah prosedur yang didasarkan pada bukti sampel yang dipakai untuk menentukan apakah hipotesis merupakan suatu pernyataan yang wajar dan oleh karenanya tidak ditolak, atau hipotesa tersebut tidak wajar dan oleh karena itu harus ditolak.

\section{HASIL DAN PEMBAHASAN}

\subsection{Hasil Uji Regresi Linier Berganda Variabel Independen terhadap Keputusan TransferPricing tanpa Variabel Moderating}

Untuk membuktikan hipotesis dalam penelitian ini, maka data yang diperoleh analisis dengan model regresi linier berganda. Berdasarkan hasil penelitian tersebut, diperoleh nilai-nilai seperti berikut:

Tabel 2

Koefisien Regresi Model (1)

\begin{tabular}{|c|c|c|c|c|c|c|}
\hline \multirow{2}{*}{\multicolumn{2}{|c|}{ Model }} & \multicolumn{2}{|c|}{ Unstandarized Coefficients } & \multirow{2}{*}{$\begin{array}{c}\text { Standarized } \\
\text { Coefficients } \\
\text { Beta }\end{array}$} & \multirow[t]{2}{*}{$t$} & \multirow[t]{2}{*}{ Sig. } \\
\hline & & B & Std. Eror & & & \\
\hline \multirow[t]{4}{*}{1} & (Constant) & 1.187 & 0.140 & & 8.485 & 0.000 \\
\hline & Tunneling Incentive & -0.012 & 0.002 & -0.675 & -5.657 & 0.000 \\
\hline & Bonus Mechanism & -0.001 & 0.000 & -0.357 & -3.006 & 0.005 \\
\hline & Debt Covenant & -0.072 & 0.089 & -0.094 & -0.806 & 0.425 \\
\hline & 0.504 & & & & & \\
\hline $\mathrm{F}$ & 12.520 & & & & & \\
\hline & 0.000 & & & & & \\
\hline
\end{tabular}

Sumber : Data diolah tahun 2021

Berdasarkan tabel diatas, maka model regresi yang diperoleh adalah sebagai berikut:

$$
\begin{aligned}
& \mathrm{Y}=1.187+\left(-0,012 \mathrm{X}_{1}\right)+\left(-0,001 \mathrm{X}_{2}\right)+ \\
& \left(-0,0072 X_{3}\right)+\varepsilon
\end{aligned}
$$

Berdasarkan hasil pengujian regresi linier berganda pada tabel 1, dapat diketahui bahwa variabel tunneling incentive, mechanism bonus dan debt covenant memiliki tingkat signifikansi lebih kecil dari 0,05 sehingga Ho ditolak. Hasil ini menunjukkan bahwa baik tunneling incentive, mechanism bonus dan debt covenant berpengaruh secara signifikan terhadap keputusan transfer pricing pada perusahaan multinasional dengan tingkat signifikansi masing-masing sebesar 0,000, 0,005 dan 0,425. Penelitian ini konsisten dengan penelitian yang dilakukan oleh Yuniasih (2012) menemukan bahwa tunneling incentive berpengaruh positif pada keputusan transfer pricing, kondisi yang unik dimana kepemilikan saham pada perusahaan publik di Indonesia cenderung terkonsentrasi sehingga ada kecenderungan pemegang saham mayoritas untuk melakukan tunnelling incentive.

Sesuai teori yang ada, jika pemilik saham memiliki kepemilikan yang besar, dengan kata lain mereka telah memasukkan modal yang besar ke dalam perusahaan tersebut. Artinya, 
mereka juga menginginkan pengembalian atau dividen yang besar pula. Untuk itu saat dividen yang dibagikan perusahaan tersebut harus dibagi dengan pemilik saham minoritas, maka pemilik saham mayoritas lebih memilih untuk melakukan transfer pricing dengan cara mentransfer kekayaan perusahaan untuk kepentinganya sendiri daripada membagi dividennya kepada pemilik saham minoritas. Oleh sebab itu, semakin besar kepemilikan pemegang saham maka akan semakin memicu terjadinya praktik transfer pricing.

4.2 Hasil Uji Regresi Linier Berganda Variabel Independen dengan Variabel Moderating Tax Minimization terhadap Transfer pricing

Model regresi dalam penelitian ini memiliki unsur moderasi, sehingga untuk menganalisis data digunakan Moderated Regression Analysis (MRA) dengan menggunakan uji interaksi (pure moderator) diperoleh hasil seperti berikut:

Tabel 3.

Koefisien Regresi Model (2)

\begin{tabular}{|c|c|c|c|c|c|c|c|}
\hline \multirow{2}{*}{\multicolumn{3}{|c|}{ Model }} & \multicolumn{2}{|c|}{ Unstandarized Coefficients } & \multirow{2}{*}{$\begin{array}{c}\text { Standarized } \\
\text { Coefficients } \\
\text { Beta }\end{array}$} & \multirow[t]{2}{*}{$t$} & \multirow[t]{2}{*}{ Sig. } \\
\hline & & & B & Std. Eror & & & \\
\hline \multirow[t]{7}{*}{1} & (Con & & 1.161 & 0.148 & & 7.856 & 0.000 \\
\hline & Tunn & tive & -0.014 & 0.005 & -0.761 & -2.648 & 0.012 \\
\hline & Bonu & & -0.001 & 0.000 & -0.371 & -3.075 & 0.004 \\
\hline & Debt & & -0.123 & 0.383 & 0.162 & 0.322 & 0.749 \\
\hline & Inter & & 0.000 & 0.001 & 0.395 & 0.269 & 0.790 \\
\hline & Inter & & -0.000 & 0.000 & -0.029 & -1.396 & 0.172 \\
\hline & Intera & & -0.024 & 0.092 & -0.401 & -0.264 & 0.793 \\
\hline & quare & 0.532 & & & & & \\
\hline $\mathrm{F}$ & & 6.451 & & & & & \\
\hline $\mathrm{Si}$ & & 0.000 & & & & & \\
\hline
\end{tabular}

Sumber : Data diolah tahun 2021

Hasil pengujian regresi linier berganda pada tabel 2, dapat diketahui bahwa variabel tax minimization hanya memoderasi secara signifikan pengaruh tunneling incentive terhadap keputusan transfer pricing pada perusahaan multinasional dengan tingkat signifikansi sebesar 0,000 dengan demikian Ho ditolak. Kecenderungan perusahaan multinasional untuk meminimalkan beban pajak dengan cara meminimalkan laba melalui praktik transfer pricing akan sangat memperkuat tujuan para pemegang saham mayoritas yakni meminimalkan laba dengan mentransfer aset dan profit perusahaan untuk kepentingan mereka sendiri melalui praktik transfer pricing tersebut, sehingga perusahaan tidak perlu mendistribusikan dividen kepada pemegang saham minoritas. Sedangkan tax minimization gagal memoderasi pengaruh mekanisme bonus dan debt covenant terhadap transfer pricing. 
4.3 Uji Kelayakan Model

4.3.1 Hasil Koefisien Determinasi

Tabel 4

Koefisien Determinasi

R squared

Ajusted R squared

0.532

0.450

Sumber : Data diolah tahun 2021

Uji Koefisien diperoleh nilai Adjusted R2 sebesar 0,450 "berarti hampir setengah variabel independen mampu menjelaskan variasi dari variabel dependen dengan variabel moderisasi sebesar $45 \%$ ", sedangkan sisanya sebesar 55\% dapat dilihat dengan faktor lain yang tidak ada model.

\subsubsection{Uji Hipotesis (Uji Statistik T)}

Tabel 5

Uji Hipotesis (Uji T)

Coefficients $^{\mathrm{a}}$

\begin{tabular}{|c|c|c|c|c|c|c|c|c|c|c|c|}
\hline & \multirow{2}{*}{ Model } & \multicolumn{2}{|c|}{$\begin{array}{l}\text { Unstandarized } \\
\text { Coefficients }\end{array}$} & \multirow{2}{*}{$\begin{array}{c}\text { Standarized } \\
\text { Coefficients } \\
\text { Beta }\end{array}$} & \multirow[t]{2}{*}{$\mathbf{t}$} & \multirow[t]{2}{*}{ Sig. } & \multicolumn{3}{|c|}{ Correlations } & \multicolumn{2}{|c|}{$\begin{array}{l}\text { Collinearity } \\
\text { Statistics }\end{array}$} \\
\hline & & B & $\begin{array}{l}\text { Std. } \\
\text { Eror }\end{array}$ & & & & $\begin{array}{l}\text { Zero- } \\
\text { order }\end{array}$ & Partial & Part & Tolerance & VIF \\
\hline \multirow[t]{7}{*}{1} & (Constant) & 1.161 & 0.148 & & 7.856 & 0.000 & & & & & \\
\hline & $\begin{array}{l}\text { Tunneling } \\
\text { Incentive }\end{array}$ & -0.14 & 0.005 & -0.761 & -2.648 & 0.012 & -0.610 & -0.414 & -0.311 & 0.167 & 5.999 \\
\hline & $\begin{array}{l}\text { Bonus } \\
\text { Mechanism }\end{array}$ & -0.01 & 0.000 & -0.371 & -3.075 & 0.004 & -0.213 & -0.466 & -0.361 & 0.946 & 1.057 \\
\hline & $\begin{array}{l}\text { Debt } \\
\text { Covenant }\end{array}$ & 0.123 & 0.383 & 0.162 & 0.322 & 0.749 & 0.055 & 0.055 & 0.038 & 0.055 & 18.318 \\
\hline & TI TM & 0.000 & 0.001 & 0.395 & 0.269 & 0.790 & 0.046 & 0.046 & 0.031 & 0.006 & 157.745 \\
\hline & BM TM & $-9.197 E-5$ & 0.000 & -0.029 & -1.396 & 0.172 & -0.233 & -0.233 & -0.164 & 0.614 & 1.628 \\
\hline & DB TM & -0.024 & 0.092 & -0.401 & -0.264 & 0.793 & -0.045 & -0.045 & -0.031 & .006 & 167.546 \\
\hline
\end{tabular}

a. Dependent Variable Transfer Pricing

Sumber : Data diolah tahun 2021

1) Pengujian secara individu antara variabel tunnelling incentive terhadap variabel transfer pricing.

Uji Sig adalah sebagai berikut, dimana nilai $\operatorname{sig}(0,012)<$ nilai a $(0,05)$. Jika nilai probabilitas lebih kecil atau sama dengan nilai probibalitas sig atau $(0,05>$ sig $)$ maka $\mathrm{H}_{0}$ ditolak. Nilai t tabel dapat dilihat pada tabel pada taraf signifikan 0,05 dimana $\mathrm{df}=$ jumlah sampel - jumlah variabel $-1=60-6-1=57 . T$ tabel pada df $53=$ 2,005 sedangkan $t$ hitung diperoleh pada tabel di atas (coefficients), dimana diketahui besarnya $\mathrm{t}$ hitung variabel tunnelling incentive (X1) dan transfer pricing $(\mathrm{Y})=(-2,648)$ yang berarti $\mathrm{t}$ hitung $<\mathrm{t}$ tabel $((-2,648)<2,005)$, maka $\mathrm{H}_{0}$ ditolak dan $\mathrm{Ha}$ diterima sehingga dapat disimpulkan bahwa tidak ada pengaruh signifikan.

Hipotesisnya adalah sebagai berikut :

$\mathrm{H}_{0} \quad=$ Variabel tunnelling incentive (X1) tidak berpengaruh secara individu terhadap variabel transfer pricing $(\mathrm{Y})$.

$\mathrm{H}_{\mathrm{a}}=$ Varibel tunnelling incentive (X1) berpengaruh secara individu terhadap variabel transfer pricing $(\mathrm{Y})$.

2) Pengujian secara individu antara variabel mechanism bonus terhadap variabel transfer pricing.

Uji Sig adalah sebagai berikut, dimana nilai sig $(0,004)<$ nilai a $(0,05)$. Jika nilai probabilitas lebih kecil atau sama dengan nilai probibalitas sig atau $(0,05>\operatorname{sig})$ maka $\mathrm{H}_{0}$ ditolak. Nilai t tabel 
dapat dilihat pada tabel pada taraf signifikan 0,05 dimana $\mathrm{df}=$ jumlah sampel - jumlah variabel $-1=60-6-1=53 . \mathrm{T}$ tabel pada df $53=$ 2,005 sedangkan $t$ hitung diperoleh pada tabel di atas (coefficients), dimana diketahui besarnya $\mathrm{t}$ hitung variabel mechanism bonus (X2) dan transfer pricing $(\mathrm{Y})=(-3,075)$ yang berarti $\mathrm{t}$ hitung $<\mathrm{t}$ tabel $((-3,075)<2,005)$, maka $\mathrm{H}_{0}$ ditolak dan $\mathrm{Ha}$ diterima sehingga dapat disimpulkan bahwa tidak ada pengaruh signifikan.

Hipotesisnya adalah sebagai berikut :

$\mathrm{H}_{0} \quad=$ Variabel mechanism bonus (X2) tidak berpengaruh secara individu terhadap variabel transfer pricing $(\mathrm{Y})$.

$\mathrm{H}_{\mathrm{a}}=$ Varibel tunnelling incentive (X2) berpengaruh secara individu terhadap variabel transfer pricing $(\mathrm{Y})$.

3) Pengujian secara individu antara variabel debt covenant terhadap variabel transfer pricing.

Uji Sig adalah sebagai berikut, dimana nilai $\operatorname{sig}(0,749)>$ nilai a $(0,05)$. Jika nilai probabilitas lebih kecil atau sama dengan nilai probibalitas sig atau $(0,05<$ sig $)$ maka $\mathrm{H}_{0}$ diterima. Nilai $\mathrm{t}$ tabel dapat dilihat pada tabel pada taraf signifikan 0,05 dimana $\mathrm{df}=$ jumlah sampel jumlah variabel $-1=60-6-1=53$. $T$ tabel pada df $53=2,005$ sedangkan thitung diperoleh pada tabel di atas (coefficients), dimana diketahui besarnya $t$ hitung variabel debt covenant (X3) dan transfer pricing $(\mathrm{Y})=0,322$ yang berarti $\mathrm{t}$ hitung $<\mathrm{t}$ tabel $(0,322<2,005)$, maka $\mathrm{H}_{0}$ diterima dan $\mathrm{Ha}$ ditolak sehingga dapat disimpulkan bahwa tidak ada pengaruh signifikan.

Hipotesisnya adalah sebagai berikut :

$\mathrm{H}_{0}=$ Variabel debt covenant (X3) berpengaruh secara individu terhadap variabel transfer pricing $(\mathrm{Y})$.

$\mathrm{H}_{\mathrm{a}} \quad=$ Varibel debt covenant (X3) tidak berpengaruh secara individu terhadap variabel transfer pricing $(\mathrm{Y})$.

4) Pengujian secara individu antara variabel tunnelling incentive dengan tax minimization sebagai pemoderisasi terhadap variabel transfer pricing.
Uji Sig adalah sebagai berikut, dimana nilai $\operatorname{sig}(0,790)>$ nilai a $(0,05)$. Jika nilai probabilitas lebih kecil atau sama dengan nilai probibalitas sig atau $\left(0,05<\right.$ sig) maka $\mathrm{H}_{0}$ diterima. Nilai $\mathrm{t}$ tabel dapat dilihat pada tabel pada taraf signifikan 0,05 dimana $\mathrm{df}=$ jumlah sampel jumlah variabel $-1=60-6-1=53$. $\mathrm{T}$ tabel pada df $53=2,005$ sedangkan thitung diperoleh pada tabel di atas (coefficients), dimana diketahui besarnya t hitung variabel tunnelling incentive (X1) dengan tax minimization (Z) sebagai pemoderisasi dan transfer pricing $(\mathrm{Y})=0,269$ yang berarti $t$ hitung $<\mathrm{t}$ tabel $(0,269<2,005)$, maka $\mathrm{H}_{0}$ diterima dan $\mathrm{Ha}$ ditolak sehingga dapat disimpulkan bahwa tidak ada pengaruh signifikan.

Hipotesisnya adalah sebagai berikut :

$\mathrm{H}_{0} \quad=$ Variabel tunnelling incentive (X4) dengan tax minimization sebagai pemoderisasi terhadap variabel transfer pricing $(\mathrm{Y})$.

$\mathrm{H}_{\mathrm{a}}=$ Varibel tunnelling incentive (X4) dengan tax minimization sebagai pemoderisasi terhadap variabel transfer pricing $(\mathrm{Y})$.

5) Pengujian secara individu antara variabel mechanism bonus dengan tax minimization sebagai pemoderisasi terhadap variabel transfer pricing.

Uji Sig adalah sebagai berikut, dimana nilai sig $(0,172)>$ nilai a $(0,05)$. Jika nilai probabilitas lebih kecil atau sama dengan nilai probibalitas sig atau $(0,05<$ sig $)$ maka $\mathrm{H}_{0}$ diterima. Nilai $\mathrm{t}$ tabel dapat dilihat pada tabel pada taraf signifikan 0,05 dimana $\mathrm{df}=$ jumlah sampel jumlah variabel $-1=60-6-1=53$. $\mathrm{T}$ tabel pada df $53=2,005$ sedangkan $t$ hitung diperoleh pada tabel di atas (coefficients), dimana diketahui besarnya thitung variabel mechanism bonus (X2) dengan tax minimization $(\mathrm{Z})$ sebagai pemoderisasi dan transfer pricing $(\mathrm{Y})=(-1,396)$ yang berarti thitung $<\mathrm{t}$ tabel $((-1,396)<2,005)$, maka $\mathrm{H}_{0}$ diterima dan $\mathrm{Ha}$ ditolak sehingga dapat disimpulkan bahwa tidak ada pengaruh signifikan.

Hipotesisnya adalah sebagai berikut :

$\mathrm{H}_{0} \quad=$ Variabel mechanism bonus (X4) dengan tax minimization ( $\mathrm{Z}$ ) sebagai pemoderisasi terhadap variabel transfer pricing $(\mathrm{Y})$. 
$\mathrm{H}_{\mathrm{a}} \quad=$ Varibel mechanism bonus (X4) dengan tax minimization $(\mathrm{Z})$ sebagai pemoderisasi terhadap variabel transfer pricing $(\mathrm{Y})$.

6) Pengujian secara individu antara variabel debt covenant dengan tax minimization sebagai pemoderisasi terhadap variabel transfer pricing.

Uji Sig adalah sebagai berikut, dimana nilai $\operatorname{sig}(0,793)>$ nilai a $(0,05)$. Jika nilai probabilitas lebih kecil atau sama dengan nilai probibalitas sig atau $(0,05<$ sig $)$ maka $\mathrm{H}_{0}$ diterima. Nilai $\mathrm{t}$ tabel dapat dilihat pada tabel pada taraf signifikan 0,05 dimana $\mathrm{df}=$ jumlah sampel jumlah variabel $-1=60-6-1=53$. $\mathrm{T}$ tabel pada df $53=2,005$ sedangkan thitung diperoleh pada tabel di atas (coefficients), dimana diketahui besarnya $\mathrm{t}$ hitung variabel debt coveanant (X3) dengan tax minimization $(\mathrm{Z})$ sebagai pemoderisasi dan transfer pricing $(Y)=(-0,264)$ yang berarti $t$ hitung $<\mathrm{t}$ tabel $((-0,264)<2,005)$, maka $\mathrm{H}_{0}$ diterima dan $\mathrm{Ha}$ ditolak sehingga dapat disimpulkan bahwa tidak ada pengaruh signifikan.

Hipotesisnya adalah sebagai berikut :

$\mathrm{H}_{0} \quad=$ Variabel debt covenant (X4) dengan tax minimization $(Z)$ sebagai pemoderisasi terhadap variabel transfer pricing $(\mathrm{Y})$.

$\mathrm{H}_{\mathrm{a}} \quad=$ Varibel debt covenant (X4) dengan tax minimization $(\mathrm{Z})$ sebagai pemoderisasi terhadap variabel transfer pricing $(\mathrm{Y})$.

\subsubsection{Uji Signifikansi Simultan (Uji Statistik F)}

Tabel 6

Uji Signifikansi Simultan (Uji F)

ANOVA $^{a}$

\begin{tabular}{llrrrrr}
\hline \multicolumn{1}{c}{ Model } & \multicolumn{1}{c}{$\begin{array}{c}\text { Sum of } \\
\text { Squares }\end{array}$} & df & $\begin{array}{c}\text { Mean } \\
\text { Square }\end{array}$ & F & \multicolumn{1}{c}{ Sig. } \\
\hline 1 & Regression & 3.660 & 6 & 0.610 & 6.451 & $0.000^{\mathrm{b}}$ \\
& Residual & 3.214 & 34 & 0.095 & & \\
Total & 6.874 & 40 & & & \\
\hline
\end{tabular}

a. Dependent Variable : TransferPrincing

b. Predictors : (constant), DBTM, MechanismBonus, MBTM, TunnellingIncentive, DebtCovenant, TITM Sumber : Data diolah tahun 2021

Uji Sig adalah sebagai berikut, dimana nilai $\operatorname{sig}(0,000)<$ nilai a $(0,05)$. Jika nilai probabilitas lebih besar atau sama dengan nilai probabilitas Sig atau $(0.05 \geq$ Sig), maka Ho ditolak, artinya tidak ada pengaruh signifikan. Nilai $f$ tabel dapat dilihat pada tabel pada taraf signifikan 0,05 dimana $\mathrm{df}=$ jumlah sampel - jumlah variabel $=60-6=54 . \mathrm{F}$ tabel pada $\mathrm{df} 27=2,272$ sedangkan $\mathrm{f}$ hitung diperoleh pada tabel di atas (coefficients), dimana diketahui besarnya $\mathrm{f}$ hitung variabel $\mathrm{X} 1, \mathrm{X} 2, \mathrm{X} 3, \mathrm{X} 4, \mathrm{X} 5$, serta $\mathrm{X} 6$ dan transfer pricing $(\mathrm{Y})=6,451$ yang berarti $\mathrm{f}$ hitung $>$ f tabel $(6,451>2,272)$, maka $\mathrm{H}_{0}$ ditolak dan $\mathrm{Ha}$ diterima sehingga dapat disimpulkan bahwa ada pengaruh signifikan.

Hipotesisnya adalah sebagai berikut :

$\mathrm{H}_{0} \quad=$ Variabel tunnelling incentive, mechanism bonus, debt covenant, tunnelling incentive dengan tax minimization sebagai pemoderisasi, mechanism bonus dengan tax minimization sebagai pemoderisasi debt covenant dengan tax minimization sebagai pemoderisasi $(\mathrm{X} 1, \mathrm{X} 2, \mathrm{X} 3, \mathrm{X} 4, \mathrm{X} 5$ dan $\mathrm{X} 6)$ tidak berpengaruh secara individu terhadap variabel penyerapan tenaga kerja $(\mathrm{Y})$.

$\mathrm{H}_{\mathrm{a}}=$ Variabel tunnelling incentive, mechanism bonus, debt covenant, tunnelling incentive dengan tax minimization sebagai pemoderisasi, mechanism bonus dengan tax minimization sebagai pemoderisasi debt covenant dengan tax minimization sebagai pemoderisasi $(\mathrm{X} 1, \mathrm{X} 2, \mathrm{X} 3, \mathrm{X} 4, \mathrm{X} 5$ dan $\mathrm{X} 6)$ berpengaruh secara individu terhadap variabel penyerapan tenaga kerja (Y). 
4.4 Hasil Analisa Regresi

4.4.1 Uji Asumsi Klasik

4.4.1.1 Uji Multikolinearitas

1. Melihat multikolinearitas dengan VIF

Tabel 7

Uji Multikolinearitas dengan VIF

Coefficients $^{a}$

\begin{tabular}{|c|c|c|c|c|c|c|c|c|c|c|c|}
\hline & \multirow{2}{*}{ Model } & \multicolumn{2}{|c|}{$\begin{array}{l}\text { Unstandarized } \\
\text { Coefficients }\end{array}$} & \multirow{2}{*}{$\begin{array}{c}\text { Standarized } \\
\text { Coefficients } \\
\text { Beta }\end{array}$} & \multirow[t]{2}{*}{$\mathbf{t}$} & \multirow[t]{2}{*}{ Sig. } & \multicolumn{3}{|c|}{ Correlations } & \multicolumn{2}{|c|}{$\begin{array}{c}\text { Collinearity } \\
\text { Statistics }\end{array}$} \\
\hline & & B & $\begin{array}{l}\text { Std. } \\
\text { Eror }\end{array}$ & & & & $\begin{array}{l}\text { Zero- } \\
\text { order }\end{array}$ & Partial & Part & Tolerance & VIF \\
\hline \multirow[t]{7}{*}{1} & (Constant) & 1.161 & 0.148 & & 7.856 & 0.000 & & & & & \\
\hline & $\begin{array}{l}\text { Tunneling } \\
\text { Incentive }\end{array}$ & -0.14 & 0.005 & -0.761 & -2.648 & 0.012 & -0.610 & -0.414 & -0.311 & 0.167 & 5.999 \\
\hline & $\begin{array}{l}\text { Bonus } \\
\text { Mechanism }\end{array}$ & -0.01 & 0.000 & -0.371 & -3.075 & 0.004 & -0.213 & -0.466 & -0.361 & 0.946 & 1.057 \\
\hline & $\begin{array}{l}\text { Debt } \\
\text { Covenant }\end{array}$ & 0.123 & 0.383 & 0.162 & 0.322 & 0.749 & 0.055 & 0.055 & 0.038 & 0.055 & 18.318 \\
\hline & TI TM & 0.000 & 0.001 & 0.395 & 0.269 & 0.790 & 0.046 & 0.046 & & 0.006 & 157.745 \\
\hline & BM TM & $-9.197 E-5$ & 0.000 & -0.029 & -1.396 & 0.172 & -0.233 & -0.233 & -0.164 & 0.614 & 1.628 \\
\hline & DB TM & -0.024 & 0.092 & -0.401 & -0.264 & 0.793 & -0.045 & -0.045 & -0.031 & .006 & 167.546 \\
\hline
\end{tabular}

a. Dependent Variable Transfer Pricing

Sumber : Data diolah tahun 2021

Dalam tabel coefficient dapat diketahui bahwa nilai standar error kurang dari satu yaitu $X 1=0.005, X 2=0.000, X 3=0,383, X 4=0.001$, $X 5=0.000$, dan $X 6=0.092$. Serta nilai koefisien beta juga kurang dari satu dimana $X 1=(-0.761)$ , X2 $=(-0.371), X 3=0.162, X 4=0.395, X 5=(-0.209)$ dan X6=(-0.401). Maka dapat dikatakan bahwa nilai standar error rendah dan multikolinearitas tidak terdeteksi.

Berdasarkan pengujian di atas, dapat diketahui bahwa nilai tolerance variabel X1=0.167, X2=0.946 dan X5=0.614 lebih besar dari 0,10 , sedangkan $\mathrm{X} 3=0.055, X 4=0.006$ dan $\mathrm{X} 6=0.006$ kurang dari 0,10.

Berdasarkan pengujian di atas, dapat diketahui nilai VIF X1=5.999, VIF X2=1.057 dan VIF $X 5=1.628$. Karena nilai VIF untuk semua variabel tersebut $<10$, sedangkan $X 3=18.318$, VIF X4=157.745 dan VIF X6=167.546. Maka dapat disimpulkan tidak terjadi gangguan multikolinearitas atau dengan kata lain model regresi ini terbebas dari gejala multikolinearitas (rentangnya sempit).

2. Melihat multikolinearitas dari eigenvalue

Tabel 8

Uji Multikolinearitas dengan Eigenvalue Collinearity Diagnostics ${ }^{a}$

\begin{tabular}{|c|c|c|c|c|c|c|c|c|c|c|}
\hline \multirow{3}{*}{\multicolumn{2}{|c|}{ Model }} & \multirow{3}{*}{$\begin{array}{l}\text { Eigen } \\
\text { Value }\end{array}$} & \multirow{3}{*}{$\begin{array}{l}\text { Condition } \\
\text { Index }\end{array}$} & \multicolumn{7}{|c|}{ Variance Proportions } \\
\hline & & & & \multirow{2}{*}{ (Constant) } & \multirow{2}{*}{$\begin{array}{l}\text { Tunneling } \\
\text { Incentive }\end{array}$} & \multirow{2}{*}{$\begin{array}{c}\text { Bonus } \\
\text { Mechanism }\end{array}$} & \multirow{2}{*}{$\begin{array}{c}\text { Debt } \\
\text { Covenant }\end{array}$} & \multirow{2}{*}{$\begin{array}{c}\mathrm{TI} \\
\mathrm{TM}\end{array}$} & \multirow{2}{*}{$\begin{array}{l}\mathrm{BM} \\
\mathrm{TM}\end{array}$} & \multirow{2}{*}{$\begin{array}{l}\mathrm{DB} \\
\mathrm{TM}\end{array}$} \\
\hline & & & & & & & & & & \\
\hline 1 & 1 & 3.757 & 1.000 & 0.01 & 0.00 & 0.00 & 0.00 & 0.00 & 0.01 & 0.00 \\
\hline & 2 & 1.138 & 1.817 & 0.00 & 0.00 & 0.08 & 0.00 & 0.00 & 0.13 & 0.00 \\
\hline & 3 & 1.030 & 1.910 & 0.00 & 0.00 & 0.52 & 0.00 & 0.00 & 0.19 & 0.00 \\
\hline & 4 & 0.824 & 2.135 & 0.02 & 0.01 & 0.32 & 0.00 & 0.00 & 0.15 & 0.00 \\
\hline & 5 & 0.186 & 4.494 & 0.01 & 0.02 & 0.03 & 0.06 & 0.00 & 0.50 & 0.00 \\
\hline & 6 & 0.062 & 7.810 & 0.94 & 0.14 & 0.05 & 0.01 & 0.00 & 0.03 & 0.00 \\
\hline & 7 & 0.002 & 43.171 & 0.02 & 0.83 & 0.00 & 0.92 & 1.00 & 0.00 & 1.00 \\
\hline
\end{tabular}

a. Dependent Variable Transfer Pricing

Sumber : Data diolah tahun 2021 
Berdasarkan pengujian di atas, dapat disimpulkan bahwa nilai eigenvalue $\mathrm{X} 1=1.138$, eigenvalue $\mathrm{X} 2=1.130$, eigenvalue $\mathrm{X} 3=0.824$, eigenvalue $\mathrm{X} 4=0.186$, eigenvalue $\mathrm{X} 5=0.062$ dan eigenvalue $\mathrm{X} 6=0.002$. Kemudian, nilai condition index $\mathrm{X} 1=1.187, \mathrm{X} 2=1.910, \mathrm{X} 3=2.135, \mathrm{X} 4=4.494$, $\mathrm{X} 5=7.810$ dan $\mathrm{X} 6=43.171$. Karena nilai eigenvalue untuk X1, X2, X3,X4 dan X5 yaitu > 0,01, sedangkan eigenvalue $\mathrm{X} 6$ yaitu $<0,01$. Nilai condition index untuk X1, X2, X3,X4 dan X5 yaitu $<30$, sedangkan condition index untuk X6 yaitu $>30$ maka dapat disimpulkan gejala multikolinearitas tidak terjadi pada regresi.

\subsubsection{Uji Autokorelasi}

Tabel 9.

Uji Autokorelasi

Model Summaryb

\begin{tabular}{|c|c|c|c|c|c|c|c|c|c|c|}
\hline \multirow[b]{2}{*}{ Model } & \multirow[t]{2}{*}{$\mathbf{R}$} & \multirow{2}{*}{$\begin{array}{c}\mathbf{R} \\
\text { Square }\end{array}$} & \multirow{2}{*}{$\begin{array}{l}\text { Adjusted } \\
\text { R Square }\end{array}$} & \multirow{2}{*}{$\begin{array}{l}\text { Std. } \\
\text { Eror of } \\
\text { the } \\
\text { Estimate }\end{array}$} & \multicolumn{5}{|c|}{ Change Statistics } & \multirow{2}{*}{$\begin{array}{l}\text { Durbin- } \\
\text { Watson }\end{array}$} \\
\hline & & & & & $\begin{array}{c}\text { R } \\
\text { Square } \\
\text { Change }\end{array}$ & $\begin{array}{c}\text { F } \\
\text { Change }\end{array}$ & df1 & df2 & $\begin{array}{l}\text { Sig. F } \\
\text { Change }\end{array}$ & \\
\hline 1 & $0.730^{\mathrm{a}}$ & 0.532 & 0.450 & 0.30748 & 0.532 & 6.451 & 6 & 34 & 0.000 & 1.106 \\
\hline
\end{tabular}

Berdasarkan tabel output "Model Summary" di atas, diketahui Durbin-Watson (d) adalah sebesar 1.106.

Durbin-Watson tabel :

$(\mathrm{k} ; \mathrm{N})$

$(6 ; 60)$

Durbin-Watson hitung : Durbin-Watson tabel $1.106<1,639(\mathrm{dU})$

Maka sebagaimana dasar pengambilan keputusan dalam uji Durbin-Watson diatas, dapat disimpulkan bahwa terdapat masalah atau terdapat gejala autokorelasi.

\subsubsection{Uji Heteroskedastisitas}

\section{Gambar 1.}

\section{Uji Heteroskedastisitas}

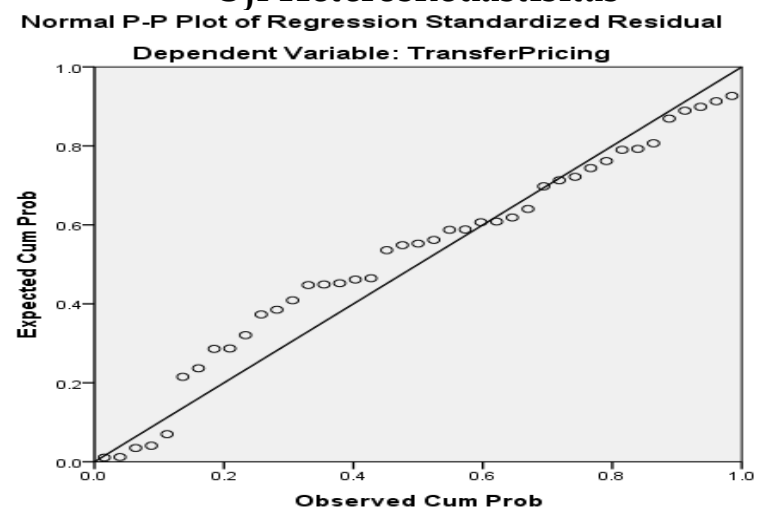

Sumber : Data diolah tahun 2021
Berdasarkan output scatterplots di atas diketahui bahwa :

a. Titik-titik data penyebaran di atas dan di bawah atau di sekitar angka 0 .

b. Titik-titik mengumpul hanya di atas dan di bawah saja.

c. Penyebaran titik-titik data tidak membentuk pola bergelombang melebar kemudian menyempit dan melebar kembali.

d. Penyebaran titik-titik data tidak berpola.

Dengan demikian, dapat kita simpulkan bahwa tidak terjadi masalah heteroskedastisitas, hingga model regresi baik dan ideal dapat terpenuhi.

\subsection{Pembahasan Hasil Penelitian}

4.5.1 Pengaruh tunnelling incentive terhadap keputusan transfer pricing.

Hasil uji parsial menunjukkan bahwa tunnelling incentive mempunyai pengaruh yang signifikan terhadap keputusan melakukan transfer pricing. Hal ini sejalan dengan pemikiran yang diutarakan oleh Yuniasih et al., (2012) menemukan bahwa tindakan tunnelling incentive berpengaruh positif pada ketentuan transfer pricing ", kondisi untuk konsentrasi ekuitas perusahaan terdaftar di Indonesia 
untuk tunnelling incentive oleh pemegang saham utama.

Hal tersebut dapat dilakukan dengan menjual aset, pemberian pinjaman, dan lainlain Serta, pemegang saham pengendali atau mayoritas dapat meningkatkan porsi atas perusahaan tanpa harus memindahkan aset melalui penerbitan saham dilutif maupun transaksi keuangan lainnya yang mengakibatkan kerugian bagi pemegang saham non pengendali atau minoritas.

\subsubsection{Pengaruh mechanism bonus terhadap keputusan transfer pricing.}

Hasil uji parsial menunjukkan bahwa mechanism bonus mempunyai pengaruh yang signifikan terhadap keputusan melakukan transfer pricing. Hal ini sejalan dengan pemikiran yang diutarakan oleh Hartati (2015), besarnya mechanism bonus berpengaruh terhadap keputusan transfer pricing.

Pemberian rencana bonus dimana batas atas bonus sebagian bergantung pada rasio pembayaran dividen perusahaan (untuk mengurangi masalah retensi dividen), membayar manajer lebih berdasarkan pergerakan harga saham ketika manajer mendekati masa pensiun (untuk mengurangi masalah horizon), membayar bonus pada tingkat progresif ketika keuntungan yang dilaporkan meningkat (untuk meminimalkan masalah penghindaran risiko) dan remunerasi manajer dikurangi dengan kompensasi berbasis saham ketika kepemilikan manajer di perusahaan meningkat (untuk mengurangi masalah penghindaran risiko).

\subsection{Pengaruh debt covenant terhadap keputusan transfer pricing.}

Hasil uji parsial menunjukkan bahwa debt covenant mempunyai pengaruh yang signifikan terhadap keputusan melakukan transfer pricing. Hal ini sejalan dengan pemikiran yang diutarakan Ria et al. (2017) menunjukkan bahwa debt covenant berdampak transfer pricing.

Pengontrakan utang (debt covenant) sangat erat kaitannya dengan teori keagenan, dimana dalam prakteknya para investor selaku pemilik perusahaan mewakilkan pengelolaan sumber daya dalam perusahaan kepada pihak yang dikontrak yaitu manajer untuk dapat menghasilkan return yang menguntungkan bagi pihak perusahaan. Perantara yang digunakan untuk mengukur debt convenant adalah rasio leverage. Rasio ini berguna untuk memberikan gambaran mengenai struktur modal milik perusahaan, sehingga dapat terprediksi risiko tak tertagihnya utang dalam perusahaan.

\subsection{Pengaruh tax minimization dalam} memoderasi tunnelling incentive terhadap keputusan transfer pricing.

Hasil uji parsial menunjukkan bahwa tax minimization memoderasi secara signifikan pengaruh tunneling incentive terhadap keputusan transfer pricing pada perusahaan multinasional. Hal ini diperkuat oleh pendapat yang diutarakan oleh Nuradila \& Wibowo (2018) bahwa beban pajak yang semakin besar memicu perusahaan untuk melakukan transfer pricing dengan harapan dapat menekan beban tersebut.

Minimisasi pajak dapat mempengaruhi masalah, termasuk korporasi, hasil operasi dan kebijakan pajak karena informasi asimetris antara manajer yang menjadi agen. Upaya minimisasi pajak perusahaan dilakukan dengan mentransfer laba ke negar yang memiliki low tax rate melalui skema penentuan transfer pricing sebagai suatu penghindaran pajak. Sehingga, memungkinkan terjadinya tunnelling dalam perusahaan. Tunnelling incentive ialah salah satu strategi mentransfer sumber daya, asset dan laba keluar dari sebuah perusahaan untuk kepentingan majority shareholders dengan biaya dibebankan kepada minority shareholders. Apabila sebuah perusahaan melakukan praktik tunnelling incentive, maka mereka akan mengorbankan hak minority shareholders dengan transfer pricing. Terjadinya tunnelling incentive dengan transfer pricing diperkuat dengan adanya motivasi tax minimization.

4.5 Pengaruh tax minimization dalam memoderasi mechanism bonus terhadap keputusan transfer pricing. 
Hasil uji parsial menunjukkan tax minimization tidak memoderasi secara signifikan pengaruh bonus mechanism terhadap keputusan transfer pricing pada perusahaan multinasional. Hal ini sejalan dengan pemikiran yang diutarakan oleh (Nuradila \& Wibowo, 2018), (Amanah \& Suyono, 2020), (Rahmawati Nila \& Mulyani Susi Dwi, 2020) mengemukakan bahwa penghindaran pajak tidak dapat memitigasi dampak mekanisme bonus terhadap keputusan transfer pricing perusahaan multinasional.

Mechanism bonus yang digunakan oleh pemilik perusahaan dengan tujuan untuk memberikan apresiasi kepada dewan direksi yang telah mengelola perusahaannya dengan baik tidak memiliki pengaruh terhadap keputusan melakukan transfer pricing. Dengan diterapkannya kebijakan bonus yang tepat, maka pemilik berharap manajemen dapat meningkatkan kinerja melalui efisiensi pembayaran pajak.

\subsection{Pengaruh tax minimization dalam memoderisasi debt covenant terhadap keputusan transfer pricing.}

Hasil uji parsial menunjukkan tax minimization tidak memoderasi secara signifikan pengaruh debt covenant terhadap keputusan transfer pricing pada perusahaan multinasional. Hal ini sejalan dengan pemikiran yang diutarakan oleh Nuradila \& Wibowo (2018) akan tetapi signifikasi yang berbeda.

Ketika sebuah perusahaan memiliki tingkat debt to equity ratio (DER) yang semakin rendah, maka perusahaan memutuskan untuk menerapka transfer pricing.

\section{SIMPULAN}

Berdasarkan analisis maka simpulan sebagai berikut, Tunneling incentive berpengaruh signifikan terhadap keputusan transfer pricing pada perusahaan multinasional. Bonus mechanism berpengaruh signifikan terhadap keputusan transfer pricing pada perusahaan multinasional. Debt covenant berpengaruh signifikan terhadap keputusan transfer pricing pada perusahaan multinasional.
Tax minimization memoderasi secara signifikan pengaruh tunneling incentive terhadap keputusan transfer pricing pada perusahaan multinasional. Tax minimization tidak memoderasi secara signifikan pengaruh bonus mechanism terhadap keputusan transfer pricing pada perusahaan multinasional dan Tax minimization tidak memoderasi secara signifikan pengaruh debt covenant terhadap keputusan transfer pricing pada perusahaan multinasional.

\section{Keterbatasan dan saran untuk penelitian selanjutnya}

Berdasarkan keterbatasan penelitian ini, maka peneliti memberikan beberapa saran untuk perbaikan penelitian selanjutnya yaitu:

1. Sampel yang digunakan pada penelitian ini hanya terfokus pada perusahaan sektor manufaktur yang terdaftar di Bursa Efek Indonesia, sehingga tidak dapat digeneralisasikan pada sektor lain. Untuk penelitian selanjutnya disarankan memperbanyak sampel penelitian tidak hanya terbatas pada perusahaan multinasional sektor manufaktur saja, tapi juga pada sektor lainnya seperti keuangan, pertambangan dan lain-lain.

2. Tahun pengamatan penelitian ini terbatas tahun 2018 sampai 20120, sebaiknya penelitian selanjutnya untuk memperpanjang rentang waktu pengamatan sehingga diharapkan dapat memberikan hasil yang lebih baik.

\section{REFERENSI}

Cahyadi, A. S., \& Noviari, N. (2018). Pengaruh Pajak, Exchange Rate, Profitabilitas, Dan Leverage Pada Keputusan Melakukan Transfer Pricing Fakultas Ekonomi dan Bisnis Universitas Udayana (Unud), Bali , Indonesia Fakultas Ekonomi dan Bisnis Universi. Jurnal Akuntansi, 22(3), 1441-1473.

Hartati, W., Desmiyawati, \& Azlina, N. (2014). Analisis Pengaruh Pajak Dan Mekanisme Bonus Terhadap Keputusan Transfer Pricing (Studi Empiris Pada Seluruh Perusahaan Yang 
Listing Di Bursa Efek Indonesia). Jurnal SNA Mataram.

Hartina, A. (2018). Komite Audit Sebagai Pemoderasi Pengaruh Tax Minimization Terhadap Transfer Pricing (Studi Empiris Pada Perusahaan Manufaktur Sektor Industri Barang Konsumsi Yang Terdaftar Di Bursa Efek Indonesia Tahun 2013-2016). Jurnal Ekobis Dewantara, 1(2), 169-179.

Herawaty, V., \& Anne, A. (2019). Pengaruh Tarif Pajak Penghasilan, Mekanisme Bonus, Dan Tunneling Incentives Terhadap Pergeseran Laba Dalam Melakukan Transfer Pricing Dengan Good Corporate Governance Sebagai Variabel Moderasi. Jurnal Akuntansi Trisakti, 4(2), 141.

Marfuah dan Andri Puren Noor Azizah.2014. Pengaruh Pajak, Tunneling Incentie Dan Exchange Rate Pada Keputusan Transfer Pricing Perusahaan. JAAI Volume 18 No. 2 Desember: 20141156-165.

Mispiyanti. 2015. Pengaruh Pajak, Tunneling Incentive dan mekanisme Bonus Terhadap Keputusan Transfer Pricing. Vol 16 No.1.

Nuradila, R. F., \& Wibowo, R. A. (2018). Journal of Islamic Finance and Accounting. Tax Minimization Sebagai Pemoderasi Hubungan Antara Tunneling Incentive, Bonus Mechanism Dan Debt Convenant Dengan Keputusan Transfer Pricing, 1(1), 63-76.

Pramana, 2014. Pengaruh Pajak, Bonus Plan, Tunneling Incentive, dan Debt Covenant Terhadap Keputusan Perusahaan Untuk Melakukan Transfer Pricing (Studi Empiris pada Perusahaan Manufaktur yang Terdaftar di Bursa Efek Indonesia Tahun 2011-2013). Skripsi. Universitas Diponegoro.

Refgia, T. (2017). Pengaruh Pajak, Mekanisme Bonus, Ukuran Perusahaan, Kepemilikan Asing, Dan Tunneling Incentive Terhadap Transfer Pricing (Perusahaan Sektor Industri
Dasar Dan Kimia Yang Listing Di Bei Tahun 2011-2014). Jurnal Online Mahasiswa Fakultas Ekonomi Universitas Riau, 4(1), 543-555.

Rosa, R., Andini, R., \& Raharjo, K. (2017). Pengaruh Pajak, Tunneling Insentive, Mekanisme Bonus, Debt Covenant Dan Good Corperate Gorvernance (GCG) Terhadap Transaksi Transfer Pricing ( Studi Pada Perusahaan Manufaktur Yang Terdaftar Di Bursa Efek Indonesia Tahun 2013 - 2015 ). Journal of Accounting, 3(3), 24-35.

Saraswati, G. A. R. S., \& Sujana, I. K. (2017). Pengaruh Pajak, Mekanisme Bonus, Dan Tunneling Incentive Pada Indikasi Transfer Pricing Fakultas Ekonomi dan Bisnis Universitas Udayana (Unud), Bali, Indonesia Fakultas Ekonomi dan Bisnis Universitas U. EJurnal Akuntansi Universitas Udayana, 19(2), 1000-1029.

Sari, H. A., \& Suryarini, T. (2018). Keputusan Transfer Pricing Dipengaruhi oleh Tax Minimization, Tunneling Incentive, Mekanisme Bonus, dan Ukuran Perusahaan. Skripsi:Universitas Negeri Semarang, 1-19. Setijaningsih, H. T. (2012). Teori Akuntansi Positif dan Konsekuensi Ekonomi. Jurnal Akuntansi, XVI(03), 427-438.

Suandy, Erly. 2011. Hukum Pajak. Jakarta: Salemba Empat.

Susanti, A., \& Firmansyah, A. (2018). Determinants of transfer pricing decisions in Indonesia manufacturing companies. Jurnal Akuntansi \& Auditing Indonesia, 22(2), 8193.

Yuniasih et al., 2012. Pengaruh Pajak dan Tunneling Incentive Pada Keputusan Transfer Pricing Perusahaan Manufaktur yang Listing di Bursa Efek Indonesia. Jurnal Simposium Nasional. Universitas Trunojoyo. 